ISSN : 2087-2461

PENANGGUNG JAWAB Dekan FIKOM

Trimanah, M.Si.

Sekretaris Dekan

Dian Marhaeni K, M.Si

Ketua Penyunting Made Dwi Adnjani, M.Si

Sekretaris

Mubarok, M.Si

Bendahara

Umi Hidayah, S.H.

Dewan Penyunting

Trimanah, M.Si

Edi Ismoyo, M.Si

Suharyoso, S.Sos

Seksi Usaha

Endang Winarsih, S.Sos

Sirkulasi dan Distribusi

Novi, S.Sos

Alamat Redaksi

Fakultas Ilmu Komunikasi

Universitas Islam

Sultan Agung Semarang

Jl. Raya Kaligawe Km. 4

Po. Box 1054/SM

Semarang 50112

Telp. (024) 6583584

ext. $448 / 449$

Fax. (024) 6582455

email : jurnalfikom@yahoo.com
Inovasi Digital Public Relations Pada

Perguruan Tinggi Swasta di Kota Semarang

dalam Meningkatkan Citra

Agus Triyono

agustriyono7@gmail.com

119-126

Eksistensi Buruh Dalam Komunikasi Bipartit

(Upaya Membangun Kemitraan Antara

Buruh dan Pengusaha Secara Ideal di Kota Kretek)

Muhammad Zakki Mubarok

$127-139$

Implementasi Konsep Diri Pada Kelompok Gemes

(Gemuk Menawan Semarang)

Kajian Teoritis Psikologi Komunikasi tentang

Konsep Diri Pada Kelompok Gemes

(Gemuk Menawan Semarang)

Genta Maghvira

140-149

Representasi Perempuan dalam

Film Cinta Suci Zahrana

Urip Mulyadi

$150-158$

Kapitalisme, Budaya Dunia, Internasionalisasi Bahasa dan Nilai-Nilai Islam Pada Tayangan Periklanan Anak di Media Televisi Dalam Perspektif Bidang Kreatif Industri Periklanan

Dian Marhaeni Kurdaningsih

marhaeni@unissula.ac.id

159-172

Paparan Media Promosi Kesehatan

Dengan Pengetahuan Pencegahan Infeksi

Bagi Pengunjung Rumah Sakit

Besar Tirto Husodo

e-mail : besarundip4@gmail.com

Puspa Run Canti

173-177

Model Kampanye Pilkada Atasi Politik Uang

dan Sikap Pesimis Pemilih

(Telaah teoritis dan konsep implementasinya)

Hariyani

nhyani812@gmail.com

178-193 


\title{
IMPLEMENTASI KONSEP DIRI PADA KELOMPOK GEMES (GEMUK MENAWAN SEMARANG)
}

Kajian Teoritis Psikologi Komunikasi tentang Konsep Diri Pada Kelompok Gemes (Gemuk Menawan Semarang)

\author{
Genta Maghvira \\ Fakultas Ilmu Komunikasi Unissula
}

Abstract

Genta Maghvira. NIDN0401108701.2017. Implementation of Self-concept in the Group Gemes (Gemuk Menawan Semarang), Theoretical Study of Psychology Communication on Self-concept in The Group Gemes (Gemuk Menawan Semarang). Jurnal Makna. Fakultas Ilmu Komunikasi. Universitas Islam Sultan Agung, Semarang.

People with excess weight often referred as overweight or obese. In general, people with obese are often underestimated by others, or its often used as a joke or a laughing matter. But todays, people with obese can exist and begin to socially open-up. Its proved by many communities of people with obese that start exist in Indonesia, one of them is Gemes community (Gemuk Menawan Semarang) city of Semarang.

Gemes community or Gemuk Menawan Semarang is a group that accommodate fat people, especially in city of Semarang. This community established as a forum to share information with the main purpose is to boost self-confidence of the fats. In Gemes community, there aren't special criteria or any requirement once want to join. This community is open for any public for anyone who feels themselves fat. Gemes community does exist enough in doing socialactivities and already has published by Tribun Jateng media.

This theoretical study tries to see the phenomenon of Gemes community through psychological communication, point part, Self-concept. The study of psychology communication more emphasis on the study of interaction between human, behavior in personal and social life, including the social implication of the psyche of a man. Self-concept is part of the psychology communication section interpersonal communication. Self-concept is defined as understanding of oneself arising from interactions with others. Self-concept splits in two, positive self-concept and negative self-concept. Implementation of the Self-concept in this theoretical study is intented to look at how Self-concept is apllied in Gemes community. how then people with obese can feel more confidence in social life is form of positive Self-concept applied.

\section{Abstrak}

Genta Maghvira. NIDN 0401108701. 2017. Implementasi Konsep Diri Pada Kelompok Gemes (Gemuk Menawan Semarang), Kajian Teoritis Psikologi Komunikasi tentang Konsep Diri Pada Kelompok Gemes (Gemuk Menawan Semarang). Jurnal Makna. Fakultas Ilmu Komunikasi. Universitas Islam Sultan Agung, Semarang.

Orang dengan berat badan yang lebih, sering disebut dengan gemuk atau gendut. Umumnya orang gemuk sering dipandang sebelah mata dan sering dijadikan bahan candaan dan tertawaan. Namun, sekarang orang gemuk bisa eksis dan mulai membuka diri dalam pergaulan sosial. Terbukti dengan banyaknya komunitas orang gemuk yang ada di Indonesia, salah satunya yaitu Komunitas Gemes (Gemuk Menawan Semarang) kota Semarang.

Komunitas Gemes atau Gemuk Menawan Semarang ini merupakan komunitas yang menampung orang-orang gemuk khususnya yang berada di kota Semarang. Komunitas ini didirikan sebagai wadah untuk saling berbagi informasi dengan tujuan utama yaitu untuk meningkatkan kepercayaan diri. Dalam komunitas Gemes, tidak ada kriteria atau syarat 
tertentu ketika ingin bergabung dengan komunitas tersebut. Komunitas ini terbuka untuk semua kalangan masyarakat bagi kepada siapa saja yang merasa dirinya gemuk. Komunitas Gemes ini cukup eksis melakukan kegiatan sosial dan terliput oleh media Tribun Jateng.

Penelitian kajian teoritis ini mencoba melihat fenomena terbentuknya komunitas Gemes melalui sudut pandang psikologi komunikasi khususnya konsep diri. Dalam psikologi komunikasi, kajian lebih menekankan pada aspek interaksi antarpersonal dan perilaku manusia dalam kehidupan sosial, termasuk implikasi sosial terhadap kejiwaan seorang manusia. Sedangkan konsep diri merupakan bagian dari psikologi komunikasi subbab komunikasi interpersonal. Konsep diri diartikan sebagai pemahaman tentang diri sendiri yang timbul akibat interaksi dengan orang lain. Konsep diri terbagi dua yakni konsep diri positif dan konsep diri negatif. Implementasi konsep diri dalam penelitian kajian teoritis ini dimaksudkan untuk melihat bagaimana konsep diri diterapkan dalam komunitas Gemes, bagaimana kemudian orang gemuk bisa tampil secara lebih percaya diri dalam kehidupan sosial adalah bentuk dari penerapan konsep diri yang positif.

\section{UCAPAN TERIMA KASIH}

Terima kasih kepada Irvan Aditya, Anggraeni Yesika Devi, Fariz Eko Prabowo, Azis Iskandar dan Nada Amelia Wati yang telah membantu menghubungkan dengan Ayu Hapsari dan Ivo Winda selaku anggota Komunitas Gemes.

\section{PEMBAHASAN}

\section{Pendahuluan}

Sekarang ini mungkin sudah banyak orang-orang yang mengalami kegemukan atau obesitas. Hal ini bisa disebabkan karena faktor makanan yang semakin bervariatif dan sedikitnya orang yang berolahraga karena lingkungan yang tidak menunjang untuk berolah raga, kurangnya taman sosial dan semakin banyaknya gedung perkantoran, serta kemauan berolah raga yang rendah.

Mengutip data Riskesdas (Riset Kesehatan Dasar) tahun 2013, kegemukan atau obesitas sentral merupakan kondisi sebagai faktor risiko yang berkaitan erat dengan beberapa penyakit kronis. Dikatakan obesitas sentral apabila laki-laki memiliki lingkar perut $>90 \mathrm{~cm}$, atau perempuan dengan lingkar perut $>80 \mathrm{~cm}$. Secara nasional, prevalensi obesitas sentral adalah 26.6 persen, lebih tinggi dari prevalensi pada tahun 2007 (18,8\%). Secara nasional masalah gemuk pada anak usia 5-12 tahun masih tinggi, yakni, 18,8 persen, terdiri atas gemuk 10,8 persen dan sangat gemuk (obesitas) 8,8 persen. Sedangkan prevalensi gemuk pada remaja usia 13-15 tahun sebesar 10,8 persen, terdiri atas 8,3 persen gemuk dan 2,5 persen sangat gemuk (obesitas).
Dalam perspektif komunikasi, banyak stigma terhadap orang gemuk yang terus menyebar dan mengglobal, stigma tersebut mengatakan bahwa Big is not Beautiful. Studi terbaru bahkan menunjukan jumlah negara yang melihat kegemukan tanpa citra negatif terus menyusut dari tahun ke tahun. Itu artinya, keinginan global akan tubuh langsing terus meningkat. Dikutip dari laman Kesehatan dari Kompas.com pada tahun 2011, Alexandra Brewis, seorang antropolog dari Universitas State Arizona, mencermati dalam beberapa tahun terakhir ini masyarakat yang semula berpandangan terbuka terhadap tubuh gemuk makin mengidolakan bentuk tubuh langsing. Contoh yang paling terkenal adalah di pulau Fiji, Pasifik Selatan. Brewis yang mengunjungi pulau tersebut di tahun 1980 menemukan bahwa kegemukan dirayakan di sana. Tapi seiring datangnya televisi di pulau itu tahun 1995 padangan masyarakat langsung berubah. Gadis-gadis di Fiji mulai membandingkan diri mereka dengan bintang serial Melrose Place atau Beverly Hills 90210. Dalam sebuah survei di tahun 1998, 15\% gadis remaja di Fiji mengatakan mereka sering memancing muntah untuk mengontrol berat badannya. Angka tersebut melonjak 
dari 3 persen di tahun 1995. Arus informasi yang deras dari televisi juga membuat $74 \%$ gadis remaja merasa dirinya terlalu gemuk. Menurut Brewis di negara Barat, orang gemuk dipersepsikan sebagai orang yang malas dan kurang mengontrol diri.

Tak terkecuali di provinsi Jawa Tengah, Indonesia khususnya Semarang, orang-orang dengan berat badan berlebih juga kini kerap terlihat. Artinya masalah obesitas terjadi di mana saja dan menjadi masalah bersama. Entah masalah kesehatan yang semakin riskan, juga masalah sosial. Orang gemuk memang riskan menjadi korban bullying. Kelebihan fisiknya bak lelucon yang dapat mengocok perut. Para kaum berbobot lebih memang harus bermental baja. Menjadi bahan ejekan adalah bagian dari hidup. Kadang mungkin oknum-oknum yang sering mem-bully kaum berbobot lebih tersebut tidak sadar kalau kata-kata yang terlontar dari mulutnya cukup menyakitkan.

Penelitian ini merupakan kajian teoritis dari kasus obesitas dan perkembangan masalahnya. Obesitas disadari Penulis, bukan hanya berdampak pada kesehatan, namun juga pada kehidupan sosial. Penelitian akan dikembangkan dari observasi singkat pada sebuah komunitas beranggotakan orang gemuk di Semarang, untuk kemudian dikembangkan berdasarkan perspektif psikologi komunikasi, khususnya pada bagian Konsep Diri.

\section{Gemes (Gemuk Menawan Semarang)}

Salah hal yang paling menyakitkan adalah ketika kaum gemuk menjadi bahan tertawaan di dalam ruang sosial. Fisik yang gemuk kerap menjadi bahan candaan yang mungkin bagi mereka lucu. Sebagai manusia biasa, sama dengan manusia lain, manusia berbobot lebih juga memiliki hati. Kadang orang gemuk tersebut juga pernah ada di titik terbawah dalam hidup yang membuat kita merasa begitu terluka apabila dijadikan bahan olokan. Mengalami pem-bully-an yang ekstrem, diolok dan menjadi bahan tertawaan tentu begitu melukai hati. Orang gemuk mungkin ingin membela diri, tapi apa daya, postur tubuh memang jauh dari kata ideal.
Namun itu semua bertolak belakang dengan orang yang beranggapan bahwa orang gendut itu menarik, yaitu everybody is Interesting. Komunitas Gemes (Gemuk Menawan Semarang) menyangkal tentang pandangan tersebut yang menyatakan bahwa orang gendut itu tidak menarik. Komunitas. Komunitas Gemes menyatakan bahwah orang gemuk itu tetap menarik dan menawan.

Dalam laman tribunjateng.com terdapat laporan tentang komunitas kelompok Gemes, kelompok yang terdiri dari orangorang dengan berat badan lebih dari ideal, membentuk perkumpulan untuk saling menguatkan satu sama lain menghadapi resiko kesehatan dan resiko sosial sebagai efek dari obesitas mereka.

\section{TRIBUNJATENG.COM, SEMARANG}

"Maaf Mbak, Anda tidak dapat bekerja di sini karena berat badannya tidak proporsional."

Kalimat tersebut pernah diterima oleh Ivo Winda (26) beberapa waktu lalu ketika menanyakan balasan surat lamaran kepada sebuah perusahaan swasta di Semarang.

Perempuan asal Genuk Semarang itu menerima dengan lapang dada kalimat tersebut, alih-alih sakit hati. "Sejak kecil sudah terbiasa di-bully. Ini menjadikan saya tertantang mencari pekerjaan dan sekarang Alhamdullilah sudah bekerja sebagai sales executive perusahaan swasta," kata Ivo kepada Tribun Jateng, Sabtu (1/11) siang.

Saat ditemui di sebuah cafe, Ivo yang berat badannya 83 kilogram dan tinggi $160 \mathrm{~cm}$ ini terlihat percaya diri (pede). Ia juga tampil modis dengan celana legging warna biru, sepatu sneaker warna biru, serta handphone yang digenggamannya juga berwarna biru. Ivo merupakan ketua komunitas Gemuk Menawan Semarang atau disingkat Gemes, yang kini anggotanya sekitar 30 orang.

Komunitas yang terbentuk pada Mei 2014 ini menampung cowok maupun cewek berbadan besar, mulai dari remaja dan ada pula yang sudah nenek. Biasanya, para anggota saling berbagi informasi dengan tujuan utama meningkatkan kepercayaan 
diri. "Berbagi informasi di mana toko baju yang menyediakan ukuran-ukuran besar, tentang kesehatan dan olahraga. Kami juga menyelenggarakan kelas kecantikan. Inti dari komunitas ini adalah membuat orang-orang gemuk lebih percaya diri.

Gemuk juga bisa tampil cantik," kata perempuan yang tiga tahun silam lalu melepas masa lajangnya. Ivo mengungkapkan, beberapa teman-temannya yang gemuk awalnya minder dengan "kelebihan" berat badannya. Namun, kepercayaan diri itu tumbuh setelah mereka bergabung dengan Komunitas Gemes. Mereka berkomunikasi dan menghimpun anggotanya di antaranya lewat akun twitter@gemes024. "Ada juga di antara anggota yang akhirnya berpacaran," terangnya. (tribuncetak)

Terbentuknya komunitas Gemuk Menawan Semarang ini berawal dari butik Fats Big Size di Jalan Tegalwareng, Semarang yang dimiliki oleh Ayu Hapsari. Ayu menjalin komunikasi yang baik dengan konsumenkonsumennya yang kebanyakan orang-orang gemuk, dari situ Ayu memiliki sebuah pemikiran untuk mendirikan suatu komunitas yang belum ada di Kota Semarang yaitu komunitas yang beranggotakan orang-orang gemuk. Jika di Jakarta ada Xtra Large, di Surabaya ada Kombes di Yogyakarta ada Nyobes maka dari situlah Ayu berinsprirasi untuk mendirikan komunitas Gemes. Pada waktu itu Ayu mempunyai kerjasama dengan Prodia dan mengadakan sebuah penyuluhan kesehatan untuk orangorang yang berbadan gemuk dengan pembicara Ita Sugito yaitu salah satu pentolan dari Xtra Large Jakarta. Dipenyuluhan tersebut Ita banyak memberikan motivasi bagaimana seorang yang mempunyai badan gemuk harus percaya diri dan lain sebagainya. Dari kegiatan penyuluhan tersebutlah Ayu Hapsari mulai mendirikan komunitas Gemes pada tanggal 03 Mei 2014, dengan anggota orang-orang yang saat itu hadir di penyuluhan tersebut sebanyak 30 orang. Selain Ayu ada juga Andita yang menjadi anggotanya. Kemudian langsung dibentuk susunan kepengurusan komunitas tersebut, mulai dari ketua, sekertaris dan bendahara dan seksi-seksi lainya. Komunitas Gemes menampung laki-laki maupun perempuan yang mempuyai badan besar, anggotanya mulai dari remaja sampai yang sudah berumur. Komunitas saat ini diketuai oleh Ivo Winda. Wanita 29 tahun dengan berat badan 85 kilogram ini seketika langsung ditunjuk sebagai ketua karena memiliki ketegasan. Saat ini Ivo bekerja sebagai sales executive di salah satu perusahaan swasta di Semarang.

Kebanyakan orang gemuk mempunyai rasa kurang percaya diri dan malu terhadap dunia luar. Komunitas Gemes menjadi wadah untuk berkumpulnya orang-orang gemuk yang ada di Semarang untuk meningkatkan rasa kepercayaan diri. Selain itu komunitas ini juga menjadi tempat saling sharing dan berbagi informasi. Misalnya informasi di mana toko baju yang menyediakan ukuran-ukuran besar, tentang kesehatan dan olahraga, juga tentang penampilan dan kecantikan.

Setelah terbentuknya komunitas Gemes, mereka mulai melakukan kegiatankegiatan. Kegiatan pertama yang diadakan oleh komunitas gemuk menawan Semarang yaitu unjuk diri di Car Free Day di alun-alun Kota Semarang pada tanggal 25 Mei 2014 untuk menunjukan dan memperkenalkan kepada masyarakat bahwa di Semarang terdapat komunitas Gemes. Kemudian komunitas ini mengadakan event beauty class di Alfamart Jalan Pandanaran pada tahun yang sama. Komunitas Gemes juga mengutamakan kebersamaan di bidang sosial, salah satunya dengan diadakannya bakti sosial yang diadakan di Panti Asuhan Kedung Mundu pada tanggal 22 juni 2014. Ketika tidak ada kegiatan, tiap anggota biasanya hanya berkomunikasi dengan Group di Blackberry Messenger.

Komunitas Gemes membuka bagi siapa saja yang ingin bergabung, tanpa ada syarat apapun. Siapa saja yang merasa dirinya gemuk bisa menjadi anggota Gemes. Tidak ada peraturan yang mengekang pada kelompok. Kelompok Gemes memiliki basecamp, yang berada di rumah Ayu Hapsari yang menjabat sebagai bendahara Gemes. Walapun terbilang komunitas yang baru tetapi komunitas Gemes sudah banyak dilirik oleh media-media yang ada di Semarang, seperti Koran Sindo dan Tribun Jateng. 


\section{Hubungan Psikologi dengan Komunikasi}

Komunikasi memegang peranan penting dalam kehidupan manusia. Watzlawick, Beavin dan Jackson (dalam Syam, 2011:35) mengatakan "we can not not communicate," bahkan pada saat kita berdoa sekalipun. Komunikasi berasal dari bahasa Latin communico yang artinya membagi, dalam arti membagi gagasan, ide, atau pikiran; communicatio dalam bahasa Latin berasal dari kata communis yang berarti sama, sama disini maksudnya sama dalam makna. Komunikasi akan berlangsung dengan baik apabila selama ada kesamaan makna antara komunikator dan komunikan.

Definisi komunikasi bisa bermacammacam, bergantung dari perspektif-nya. Dari perspektif psikologi, Hovland, Janis dan Kelly (dalam Effendy, 1999) mendefinisikan komunikasi sebagai "The process by witch an individual (the communicator) transmits stimulus (usually verbal) to modify the behavior of other individuals (the audience)." Dalam konteks ini psikologi mencoba menganalisis komunikasi yang terjadi dalam individu; bagaimana pesan yang disampaikan menjadi stimulus yang menimbulkan respons bagi individu yang lain, bagaimana lambanglambang dapat bermakna dan bisa mengubah perilaku orang lain.

Psikologi sendiri merupakan disiplin ilmu yang mengkaji kejiwaan manusia sebagai makhluk ciptaan Tuhan Yang Maha Esa, dengan struktur dan fungsi yang sangat sempurna bila dibandingkan dengan makhluk tuhan lainnya. Dalam psikologi komunikasi, kajian lebih menekankan pada aspek interaksi antarpersonal dan perilaku manusia dalam kehidupan sosial, termasuk implikasi sosial terhadap kejiwaan seorang manusia.

Hubungan psikologi dan komunikasi dapat dipahami melalui beberapa pengertian, seperti:

(1) Raymond S. Ross, memberikan pengertian komunikasi sebagai "a transactional process involving cognitive sorting, selecting and sharing of symbols in such a way to help another alicit from his own experiences a meaning or responses similar that intended by the source" (proses transaksional yang meliputi pemisahan, dan pemilihan bersama lambing secara kognitif sedemikian rupa sehingga membantu orang lain untuk mengeluarkan dari pengalamannya sendiri arti atau respons yang sama dengan yang dimaksud oleh sumber).

(2) Beamer\&Varner(dalamSyam, 2011)dalam bukunya Intercultural Communication menyatakan bahwa komunikasi adalah suatu proses penyampaian pendapat, pikiran, dan perasaan kepada orang lain yang dipengaruhi oleh lingkungan sosial dan budayanya.

mencermati definisi-definisi tersebut, dapat disimpulkan bahwa komunikasi, bagaimanapun bentuk kontekstualnya, adalah peristiwa psikologis dalam diri masingmasing peserta komunikasi. Dengan kata lain, psikologi menganalisis seluruh komponen yang terlibat dalam proses komunikasi.

Pada diri komunikan (penerima komunikasi) psikologi menganalisis karakteristik manusia komunikan serta faktor-faktor internal dan eksternal yang mempengaruhi perilaku komunikasinya. Pada diri komunikator (pemberi komunikasi) psikologi melacak sifat-sifatnya dan bertanya: apayangmenyebabkansatusumberkomunikasi berhasil dalam mempengaruhi orang lain, sementara sumber pemberi komunikasi yang lain tidak. Komunikasi sangat esensial untuk pertumbuhan kepribadian manusia. Kurangnya komunikasi akan menghambat perkembangan kepribadian. komunikasi amat erat kaitannya dengan perilaku dan pengalaman kesadaran manusia.

Dalam sejarah perkembangannya, komunikasi memang dibesarkan oleh para peneliti psikologi. Nina Syam (2011:39) menyebutkan bahwa Wilbur Schramm yang disebut sebagai Bapak Ilmu Komunikasi adalah sarjana psikologi. Kurt Lewin adalah ahli psikologi dinamika kelompok. Sebagai ilmu, komunikasi dipelajari dari bermacammacam disiplin ilmu, antara lain sosiologi dan psikologi. Psikologi sebagai akar ilmu komunikasi merupakan landasan ilmiah 
kedua setelah filsafat. Singkatnya, psikologi merupakan salah satu akar ilmu komunikasi yang berusaha untuk menguraikan, meramalkan dan mengendalikan peristiwa mental dan behavioral dalam komunikasi.

\section{Konsep Diri}

Konsep diri merupakan bagian dari pembelajaran psikologi komunikasi, konsep diri umumnya terletak di subbab komunikasi interpersonal dalam psikologi komunikasi. Komunikasi interpersonal dalam perspektif psikologi komunikasi membahas tentang peristiwa-peristiwa mental dan behavioral individu selama ia melakukan komunikasi dengan orang lain. Pada tahap ini, maka penulis merasa bahwa yang dialami oleh orang-orang gemuk dalam memandang dirinya sendiri terkait dengan komunikasi interpersonal dan konsep diri dari orang gemuk tersebut. Setiap olok-olok dari orang lain yang diterima komunikan berbadan gemuk dapat diinterpretasikan sebagai hubungan komunikasi interpersonal, bagaimana kemudian orang gemuk memandang dirinya sendiri setelah kejadian tersebut terkait dengan konsep diri.

Secara garis besar menurut Riswandi (2013:64-65) konsep diri diartikan sebagai pemahaman tentang diri sendiri yang timbul akibat interaksi dengan orang lain. Konsep diri merupakan faktor yang menentukan (determinan) dalam komunikasi kita dengan orang lain. Menurut Jalaludin Rahmat dalam buku Psikologi Komunikasi, ada beberapa petunjuk orang yang memiliki konsep diri positif, yaitu sebagai berikut:

- Merasa setara dengan orang lain

- Memiliki kesadaran bahwa setiap orang mempunyai berbagai perasaan, keinginan, dan perilaku yang tidak seluruhnya disetujui oleh masyarakat

- Mampu memperbaiki dirinya karena ia sanggup mengungkapkan aspekaspek kepribadiannya yang tidak disenanginya dan mau berusaha untuk mengubahnya.

Selanjutnya dikatakan William D. Brooks dan Philip Emmert (dalam Riswandi,
2013), beberapa tanda orang dengan konsep diri negatif antara lain:

- Peka pada kritik

- Sangat responsif pada pujian

- Cenderung merasa tidak diperhatikan dan tidak disenangi oleh orang lain.

Secara garis besar, dalam psikologi interpersonal, konsep diri disebutkan sebagai semua persepsi kita terhadap aspek diri kita yang meliputi aspek fisik, aspek sosial, dan aspek psikologis, yang terbentuk karena pengalaman masa lalu kita dan interaksi kita dengan orang lain. Menurut Brian Tracy (dalam Jalaludin, 2005) konsep diri memiliki tiga bagian utama, yaitu: (1) Self-ideal (diri ideal); (2) Self-image (citra diri); (3) Self-esteem (jati diri). Ketiga elemen tersebut merupakan satu kesatuan yang membentuk kepribadian, menentukan apa yang biasa kita pikir, rasakan dan lakukan, serta akan menentukan segala sesuatu yang terjadi kepada diri kita.

Self-ideal terdiri dari harapan, impian, visi, dan idaman. Self-ideal terbentuk dari kebaikan, nilai-nilai, dan sifat-sifat yang paling kita kagumi dari diri sendiri maupun dari diri orang lain yang kita hormati. Self-ideal adalah sosok seperti apa yang paling kita inginkan untuk bisa menjadi diri kita. Bentuk ideal ini akan menuntun kita dalam membentuk perilaku. Self-image menunjukan bagaimana kita membayangkan diri sendiri, dan menentukan bagaimana kita akan bertingkah laku dalam satu situasi tertentu. Karena kekuatan selfimage semua perbaikan dalam hidup akan dimulai dari perbaikan dalam self-imageselfimage. Sedangkan Self-esteem adalah seberapa besar kita menyukai diri sendiri. Semakin baik performasi kita, secara otomatis kita akan menyukai diri sendiri. Bagian ini merupakan komponen emosional dalam kepribadian kita, karena indikator pentingnya meliputi hal-hal yang berkaitan dengan perasaan emosional seperti: bagaimana kita berpikir, bagaimana kita merasa dan bagaimana kita bertingkah laku terkait dengan perasaan kita.

\section{Analisa Akhir}

Konsep diri terbentuk dari sikap dan kebiasaan berpikir yang baik atau buruk, yang 
dikembangkan terus menerus. Dalam persepsi interpersonal, orang dengan sikap-sikap yang tidak baik dan tidak menyenangkan, akan tidak mengenakan juga bagi orang lain. Sebaliknya, orang yang menerima dirinya apa adanya, adalah orang yang tidak dibebani perasaan bersalah, dan cenderung menafsirkan orang lain secara objektif.

\section{Tabel Unit Kategori Konsep Diri}

\begin{tabular}{|l|l|l|}
\hline \multicolumn{1}{|c|}{ No. } & \multicolumn{1}{|c|}{ Unit Peristiwa } & \multicolumn{1}{|c|}{ Kategori } \\
\hline 1. & $\begin{array}{l}\text { Tagline 'Everybody is Interesting' dari Komunitas Gemes (didapat dari } \\
\text { wawancara) }\end{array}$ & Konsep diri positif \\
\hline 2. & $\begin{array}{l}\text { Perempuan asal Genuk Semarang itu menerima dengan lapang dada } \\
\text { kalimat tersebut, alih-alih sakit hati. "Sejak kecil sudah terbiasa di- } \\
\text { bully. Ini menjadikan saya tertantang mencari pekerjaan dan sekarang } \\
\text { Alhamdullilah sudah bekerja sebagai sales executive perusahaan } \\
\text { swasta," kata Ivo kepada Tribun Jateng, Sabtu (1/11) siang. }\end{array}$ & Konsep diri positif \\
\hline 3. & $\begin{array}{l}\text { Biasanya, para anggota saling berbagi informasi dengan tujuan utama } \\
\text { meningkatkan kepercayaan diri. "Berbagi informasi di mana toko baju } \\
\text { yang menyediakan ukuran-ukuran besar, tentang kesehatan dan } \\
\text { olahraga. Kami juga menyelenggarakan kelas kecantikan. Inti dari } \\
\text { komunitas ini adalah membuat orang-orang gemuk lebih percaya diri. } \\
\text { Gemuk juga bisa tampil cantik," kata perempuan yang tiga tahun silam } \\
\text { lalu melepas masa lajangnya. }\end{array}$ & Konsep diri positif \\
\hline 4. & $\begin{array}{l}\text { Ivo mengungkapkan, beberapa teman-temannya yang gemuk awalnya } \\
\text { minder dengan “kelebihan" berat badannya. Namun, kepercayaan diri itu } \\
\text { tumbuh setelah mereka bergabung dengan Komunitas Gemes. }\end{array}$ & Konsep diri positif \\
\hline 5. & $\begin{array}{l}\text { Unjuk diri di Car Free Day di alun-alun Kota Semarang pada tanggal 25 } \\
\text { Mei 2014 untuk menunjukan dan memperkenalkan kepada masyrakat } \\
\text { bahwa di Semarang terdapat komunitas Gemes. }\end{array}$ & Konsep diri positif \\
\hline Komunitas ini mengadakan event beauty class di Alfamart Jalan \\
Pandanaran pada tahun yang sama.
\end{tabular}

Dari tujuh unit peristiwa yang dihimpun, baik didapat dari hasil wawancara maupun tulisan di media massa, maka dapat dikatakan bahwa anggota komunitas Gemes memiliki konsep diri yang tergolong positif. Konsep diri ini terbentuk karena pemikiran dari tagline komunitas Gemes itu sendiri, bahwa 'Everbody is Interesting.' Anggota komunitas Gemes meyakini jika setiap individu memiliki daya tarik masing-masing yang tidak selamanya terletak pada tampilan fisik. Hal ini sama dengan yang dinyatakan dalam rumusan persepsi interpersonal, yaitu ketika seseorang menilai atau mempersepsi orang lain, berarti dia menilai atau mempersepsi dengan seluruh jiwa raga nya melalui konsep diri. Jadi ketika anggota komunitas Gemes mempersepsi bahwa setiap individu adalah menarik, maka mereka secara tidak langsug meyakini diri mereka sendiri juga menarik, terlepas dari tampilan fisik yang gemuk.

Persepsi interpersonal (dalam Riswanto, 2013) dianggap berbeda dengan persepsi objek, pada persepsi objek (fisik) kita hanya menanggapi sifat-sifat luar objek tersebut; seperti contoh ketika kita melihat papan tulis, kita tidak pernah mempersoalkan bagaimana perasaannya ketika kita amati. Pada persepsi objek, stimuli ditangkap oleh panca indera melalui benda-benda fisik, sedangkan pada persepsi interpersonal stimuli sampai kepada kita melalui lambanglambang verbal, atau grafis yang disampaikan orang lain. Pada persepsi interpersonal, kita mencoba memahami apa yang tidak tampak pada alat indra kita. Kita tidak hanya melihat perilakunya, kita juga melihat mengapa ia berperilaku seperti itu. Kita tidak hanya mencoba memahami tindakannya, tetapi juga 
motif tindakannya. Singkatnya, ketika kita mempersepsi objek, objek tidak beraksi kepada kita, sedangkan pada persepsi interpersonal terdapat reaksi dari yang dipersepsi.

Pada unit persitiwa yang diamati dari komunitas Gemes, kita bisa melihat jika masing-masing anggota berusaha menyuarakan konsep persepsi interpersonal. Ketika semua orang adalah menarik, maka bagaimanapun tampilan fisiknya, ia akan diterjemahkan melalui apa yang ia lakukan. Ketika ia berbuat baik maka ia ingin dianggap sebagai individu yang baik, dan kegemukannya tidak ada hubungan sama sekali dengan kebaikan personalnya. Demikian juga ketika komunitas Gemes mendapat respon yang positif dari lingkungan, maka mereka dihargai melalui persepsi interpersonal, bukan hanya persepsi objek.

Konsep diri positif yang bisa dilihat dari unit peristiwa yang dilakukan komunitas Gemes, terlihat jika anggota komunitas memiliki perasaan setara dengan orang lain, dan mampu memperbaiki dirinya karena ia sanggup mengungkapkan aspek-aspek kepribadiannya, yang tidak disenanginya dan mau berusaha mengubahnya. Ketika sebelumnya mereka merasa minder karena berat badan berlebih, mereka berusaha menghilangkan perasaan itu dengan melakukan hal-hal positif yang secara tidak langsung memberikan mereka perasaan setara dengan orang lain.

\section{Tabel Unit Bagian Konsep Diri}

\begin{tabular}{|c|c|c|}
\hline No. & Unit Peristiwa & Kategori \\
\hline 1. & $\begin{array}{l}\text { Tagline 'Everybody is Interesting' dari Komunitas Gemes (didapat dari } \\
\text { wawancara) }\end{array}$ & Self-ideal \\
\hline 2. & $\begin{array}{l}\text { Perempuan asal Genuk Semarang itu menerima dengan lapang dada } \\
\text { kalimat tersebut, alih-alih sakit hati. "Sejak kecil sudah terbiasa di- } \\
\text { bully. Ini menjadikan saya tertantang mencari pekerjaan dan sekarang } \\
\text { Alhamdullilah sudah bekerja sebagai sales executive perusahaan } \\
\text { swasta," kata Ivo kepada Tribun Jateng, Sabtu (1/11) siang. }\end{array}$ & Self-esteem \\
\hline 3. & $\begin{array}{l}\text { Biasanya, para anggota saling berbagi informasi dengan tujuan utama } \\
\text { meningkatkan kepercayaan diri. "Berbagi informasi di mana toko baju } \\
\text { yang menyediakan ukuran-ukuran besar, tentang kesehatan dan } \\
\text { olahraga. Kami juga menyelenggarakan kelas kecantikan. Inti dari } \\
\text { komunitas ini adalah membuat orang-orang gemuk lebih percaya diri. } \\
\text { Gemuk juga bisa tampil cantik," kata perempuan yang tiga tahun silam } \\
\text { lalu melepas masa lajangnya. }\end{array}$ & Self-esteem \\
\hline 4. & $\begin{array}{l}\text { Ivo mengungkapkan, beberapa teman-temannya yang gemuk awalnya } \\
\text { minder dengan "kelebihan" berat badannya. Namun, kepercayaan diri } \\
\text { itu tumbuh setelah mereka bergabung dengan Komunitas Gemes. }\end{array}$ & Self-esteem \\
\hline 5. & $\begin{array}{l}\text { Unjuk diri di Car Free Day di alun-alun Kota Semarang pada tanggal } \\
25 \text { Mei } 2014 \text { untuk menunjukan dan memperkenalkan kepada } \\
\text { masyrakat bahwa di Semarang terdapat komunitas Gemes. }\end{array}$ & Self-image \\
\hline 6. & $\begin{array}{l}\text { Komunitas ini mengadakan event beauty class di Alfamart Jalan } \\
\text { Pandanaran pada tahun yang sama. }\end{array}$ & Self-image \\
\hline 7. & $\begin{array}{l}\text { Komunitas Gemes juga mengutamakan kebersamaan di bidang sosial, } \\
\text { salah satunya dengan diadakannya bakti sosial yang diadakan di Panti } \\
\text { Asuhan Kedung Mundu pada tanggal } 22 \text { juni } 2014 \text {. }\end{array}$ & Self-image \\
\hline
\end{tabular}

Tagline 'Everybody is Interesting' termasuk dalam Self-ideal karena tagline tersebut mengacu pada harapan, impian, visi dan idaman dari anggota komunitas Gemes. 'Everybody is Interesting' menggambarkan pandangan yang setara bagi semua orang. Semua orang adalah menarik, entah menariknya dari fisiknya, perilakunya, sifatnya, cara berbicara, tingkah laku, kepandaian, sampai dengan ideologi yang diyakini. Setiap individu memiliki daya tarik sendiri yang tidak bisa diseragamkan. Sejak kemunculan iklan produk pemutih, produk untuk rambut hitam berkilau dan produk pelangsing badan, maka stereotype tentang cantik di Indonesia menjadi seragam; putih, 
rambut panjang hitam, dan langsing. Secara harfiah, stereotipe mempunyai arti penilaian terhadap seseorang hanya berdasarkan persepsi terhadap kelompok di mana orang tersebut dikategorikan. Jika cantik itu kompleks, yang berarti setiap individu memiliki daya tarik yang berbeda antara satu dengan yang lain, maka akan sulit mendefinisikan kata 'cantik.' Karena itu muncul stereotipe sebagai jalan pintas pemikiran yang dilakukan secara intuitif oleh manusia untuk menyederhanakan hal-hal yang kompleks dan membantu pengambilan keputusan secara cepat. Dengan hadirnya tagline 'everybody is interesting' diharapkan akan mengembalikan makna cantik yang sebenarnya, tidak seragam namun berdasarkan daya tarik individu masing-masing.

Unit peristiwa kedua termasuk Selfesteem karena Ivo, salah seorang anggota komunitas Gemes, merasa dari kecil ia di bully dan disakiti secara verbal, hal tersebut menjadikannya kuat dan kebal, hingga ia bisa merubah perspektifnya pada diri sendiri. Awalnya Ivo merasa minder dan melihat bentuk tubuhnya sebagai kekurangan. Selfesteem merupakan rasa menghargai terhadap diri sendiri. Semakin perilakunya baik dan ia berniat berbuat baik maka ia akan menghargai dirinya sebagai pribadi yang baik. Ia tidak lagi memandang kekurangan diri sebagai sesuatu yang negatif tetapi sebagai sebuah keunikan.

Unit peristiwa ketiga termasuk dalam self-seteem karena ada usaha untuk memperbaiki penampilan agar tetap menarik. Selama ini orang-orang gemuk kesulitan dalam memilih busana yang pas dibadan. Maka anggota komunitas Gemes saling berbagi informasi satu sama lain tentang toko yang menjual baju sesuai ukuran mereka. Selain itu, mereka mencari informasi seputar olah raga dan kesehatan. Olah raga bagi anggota komunitas Gemes tidak lagi bertujuan sebagai sarana untuk menurunkan berat badan, tetapi lebih diarahkan pada faktor kesehatan. Meraka menghargai diri mereka dan berusaha selalu sehat agar diri yang mereka sayangi tidak sakit.

Unit peristiwa keempat menunjukan self-esteem karena ada peningkatan rasa percaya diri dari semula rendah, setelah bergabung dengan komunitas Gemes menjadi naik. Penilaian terhadap bentuk tubuh akan berdampak pada penilaian pada keberhargaan diri. Ketika kita menilai tubuh sendiri rendah, maka kita akan menilai diri kita tidak berharga. Reber \& Reber (2010) mengatakan bahwa self-esteem diartikan sebagai taraf atau derajat seseorang dalam memberi penilaian terhadap diri sendiri. Harga diri tinggi atau self-esteem tinggi dapat merujuk pada persepsi yang tepat atau benar mengenai martabatnya sebagai seorang pribadi, termasuk keberhasilan dan pencapaiannya. Sebaliknya individu dengan self-esteem rendah mempersepsikan dirinya memiliki keterbatasan, penyimpangan atau bahkan kondisi yang tidak aman akan diri sendiri.

Unit peristiwa lima dan enam termasuk dalam bagian self-image atau menunjukan bagaimana kita membayangkan diri sendiri, dan menentukan bagaimana akan bertingkah laku dalam satu situasi tertentu. Self-image yang coba dihadirkan oleh komunitas Gemes dalam even Car Free Day dan even Beauty Class dapat diinterpretasikan sebagai cara mereka dalam mengkonstruksi diri mereka sehingga akan menimbulkan pandangan yang lebih positif dari orang lain. Orang-orang dengan badan gemuk akan tertarik untuk mengikuti mereka, dan orang-orang dengan berat badan tidak gemuk akan menilai mereka percaya diri, unik dan berani menunjukan diri dan kemampuan.

Unit peristiwa tujuh menunjukan tentang self-image berupa melakukan kegiatan yang bisa memperlihatkan kepada masyarakat bahwa komunitas Gemes peduli dengan lingkungan, fokus pada kegiatan sosial, dan mereka memiliki nilai lebih selain dari bentuk fisik yang dianggap sebagai kekurangan. Teori komparasi sosial (Dorian \& Garfinkel dalam Herabadi, 2007) menyatakan bahwa setiap orang akan membandingkan antara keadaan dirinya sendiri dengan keadaan orang lain yang mereka anggap sebagai pembanding yang realistis. Dalam hal ini komunitas Gemes melakukan tindakan sosial yang mereka anggap positif sebagai komparasi sosial yang 
mereka lakukan. Tujuannya adalah agar ada perbandingan antara diri mereka sendiri dengan orang lain, ketika mereka melihat orang lain melakukan kebaikan dan mereka menyukai hal itu, maka mereka beranggapan jika dilakukan hal yang sama oleh mereka maka mereka akan disukai juga oleh orang lain. Dengan demikian mereka melakukan kegiatan sosial sebagai wujud self-image terhadap diri sendiri.

\section{Kesimpulan}

Sekarang ini mungkin sudah banyak orang-orang yang mengalami kegemukan atau obesitas. Hal ini bisa disebabkan karena faktor makanan yang semakin bervariatif dan sedikitnya orang yang berolahraga karena lingkungan yang tidak menunjang untuk berolah raga, kurangnya taman sosial dan semakin banyaknya gedung perkantoran, serta kemauan berolah raga yang rendah.

Dalam perspektif komunikasi, banyak stigma terhadap orang gemuk yang terus menyebar dan mengglobal, stigma tersebut mengatakan bahwa Big is not Beautiful. Studi terbaru bahkan menunjukan jumlah negara yang melihat kegemukan tanpa citra negatif terus menyusut dari tahun ke tahun. Itu artinya, keinginan global akan tubuh langsing terus meningkat. Tak terkecuali di provinsi Jawa Tengah, Indonesia khususnya Semarang, orang-orang dengan berat badan berlebih juga kini kerap terlihat. Artinya masalah obesitas terjadi di mana saja dan menjadi masalah bersama. Entah masalah kesehatan yang semakin riskan, juga masalah sosial.

Namun itu semua bertolak belakang dengan orang yang beranggapan bahwa orang gendut itu menarik, yaitu everybody is Interesting. Komunitas Gemes (Gemuk Menawan Semarang) menyangkal tentang pandangan tersebut yang menyatakan bahwa orang gendut itu tidak menarik. Komunitas. Komunitas Gemes menyatakan bahwah orang gemuk itu tetap menarik dan menawan. Komunitas Gemes menampung laki-laki maupun perempuan yang mempuyai badan besar, anggotanya mulai dari remaja sampai yang sudah berumur.
Konsep diri merupakan bagian dari pembelajaran psikologi komunikasi, konsep diri umumnya terletak di subbab komunikasi interpersonal. Komunikasi interpersonal dalam perspektif psikologi komunikasi membahas tentang peristiwa-peristiwa mental dan behavioral individu selama ia melakukan komunikasi dengan orang lain. Pada tahap ini, maka penulis merasa bahwa yang dialami oleh orang-orang gemuk dalam memandang dirinya sendiri terkait dengan konsep diri dari orang gemuk tersebut. Setiap olok-olok dari orang lain yang diterima komunikan berbadan gemuk dapat diinterpretasikan sebagai hubungan komunikasi interpersonal, bagaimana kemudian orang gemuk memandang dirinya sendiri setelah kejadian tersebut terkait dengan konsep diri.

Pada bagian akhir terdapat hasil elaborasi terhadap kategori konsep diri dan bagian-bagian konsep diri yang dihubungkan dengan unit peristiwa (unit perilaku) yang dilakukan komunitas Gemes. Pada elaborasi kajian teori dan studi kasus ini didapat hasil bahwa ketika konsep diri positif maka kecenderungan perilaku seseorang akan menjadi positif juga dan terdapat peningkatan self-esteem, self-image dan self-ideal dari seseorang tersebut.

\section{DAFTAR PUSTAKA}

Rahmat, Jalaludin. 2005. Psikologi Komunikasi. Bandung: Remaja Rosdakarya

Riswandi. 2013. Psikologi Komunikasi. Yogyakarta: Graha Ilmu.

Syam, Nina W. 2011. Psikologi Sebagai Akar Ilmu Komunikasi. Bandung: Simbiosa Rekatama Media.

Uchjana Effendy, Onong. 1999. Ilmu Komunikasi Teori dan Praktek. Bandung: Remaja Rosdakarya.

http://www.depkes.go.id/article/view/ 15012300021/25-januari-hari-gizinasional.html\#sthash.XyaPTP1G. dpuf

http://health.kompas.com/read/2011/03/31/ 17235388/Stigma.Orang.Gemuk. Terus.Menyebar 